\title{
IMPLEMENTASI FILSAFAT PERENIALISME DALAM PEMBELAJARAN SEJARAH
}

\author{
Novi Triana Habsari*
}

\begin{abstract}
Abstrak
Perenialisme lahir sebagai suatu reaksi dan solusi terhadap pendidikan progresif dan atas terjadinya suatu keadaan yang mereka sebut krisis kebudayaan dalam kehidupan manusia modern. Perenialisme menentang pandangan progresivisme yang menekankan perubahan dan sesuatu yang baru. Jalan yang ditempuh oleh kaum perenialis adalah dengan jalan mundur, dengan menggunakan kembali nilai-nilai atau prinsip umum yang telah menjadi pandangan hidup yang kuat, kukuh pada zaman kuno dan abad pertengahan.

Metode pembelajaran yang digunakan oleh para kaum perenialis adalah membaca dan diskusi, yaitu membaca dan mendiskusikan karya-karya yang termashur dalam rangka mendisplinkan pikiran. Guru berperan bukan sebagai perantara antara dunia dan jiwa anak, melainkan guru juga sebagai murid yang mengalami proses belajar.
\end{abstract}

\section{Kata kunci: filsafat perenialisme, pembelajaran sejarah}

\section{Pendahuluan}

Istilah Perenialisme berasal dari bahasa latin, yakni dari akar kata perenis atau perennial yang berarti tumbuh terus menerus melalui waktu, hidup terus dari waktu kewaktu atau abadi. Pengertian ini apabila dianalogikan dengan bunga yang terus menerus mekar dari musim ke musim. Hal ini menunjukkan adanya gejala yang terus ada dan sama. Apabila gejala dari musim kemusim ini dihubungkan satu dengan yang lain seolah-olah merupakan benang dengan corak warna khas, yakni terus menerus sama. Maka pandangan ini selalu mempercayai mengenai adanya nilai-nilai, norma-norma yang bersifat abadi dalam kehidupan ini. Atas dasar itu, perenialis memandang pola perkembangan kebudayaan sepanjang zaman adalah pengulangan dari apa yang ada sebelumnya sehingga perenialisme sering disebut dengan istilah tradisionalime.

Perenialisme lahir sebagai suatu reaksi dan solusi terhadap pendidikan progresif dan atas terjadinya suatu keadaan yang mereka sebut krisis kebudayaan dalam kehidupan manusia modern. Perenialisme menentang pandangan progresivisme yang menekankan perubahan dan sesuatu yang baru. Jalan yang ditempuh oleh kaum perenialis adalah dengan jalan mundur, dengan menggunakan kembali nilai-nilai atau prinsip umum yang telah menjadi pandangan hidup yang kuat, kukuh pada zaman kuno dan abad pertengahan.

Kaum perenialis melawan kegagalan-kegagalan dan tragedi dalam abad modern ini dengan mundur kembali kepada kepercayaan yang 
aksiomatis yang telah teruji tangguh, baik mengnai hakikat realitas, pengetahuan, maupun nilai yang telah member dasar fundamental bagi abadabad sebelumnya.

\section{Ontologi Perenialisme}

Ontologis perenialisme terdiri dari penggertian-pengertian, seperti benda individual, esensi, aksiden dan substansi. Perenialisme membedakan realitas dalam aspek-aspek perwujudannya dalam tipologi istilah ini. Benda individual yang dimaksud adalah benda sebagaimana tampak di hadapan manusia dan dapat ditangkap panca indera, seperti batu, lembu, rumput, orang dalam bentuk, ukuran, warna, dan aktivitas tertentu, sep erti manusia jika ditilik dari segi esensinya yang tidak lain adalah makhluk berpikir. Adapun aksiden selau dimaknai sebagai keadaan-keadaan khusus yang berubahubah dan dipandang bersifat kurang penting jika dibandingkan dengan esensial, misalnya orang suka beermain sepaturoda atau suka berpakaian bagus, sedangkan substansi adalah kesatuan dari tiap-tiap individu, misalnya partikular dan unversal, material dan spiritual. Dalam pengertian ini, segala yang ada di alam seperti halnya manusia, hewan, tumbuh-tumbuahan, dan sebagainya, menampakkan hal logis dalam karakternya. Setiap segala sesuatu yang ada, tidak hanya merupakan padupadan antara zat atau benda, tatapi juga merupakan unsur potensial yang aktual sabagaimana yang diutarakan Aristoteles sekaligus sesuatu yang datang bersama-sama dari sesuatu yang terkandung dalam inti (essensce) dan potensialitas ini memungkinkan sesuatu menjadi ada.

Dengan demikian, segala yang ada di dalam ini terdiri dari materi dan bentuk atau badan dan jiwa disebut dengan substansi. Bila dihubungkan dengan manusia, manusia itu adalah petensialitas yang di dalam hidupnya tidak jarang dikuasai oleh sifat eksintensi keduniaan, tidak jarang pula dimilikinya akal, perasaan, dan kemauannya semua ini dapat diatasi.

Ontologis perenialisme berisikan pengertian benda individual, esensi, aksiden, dan substansi.

a. Benda individual adalah benda yang sebagaimana tampak di hadapan manuasia yang dapat ditangkap oleh indra kita, sperti batu, kayu, dan lain-lain.

b. Esensi sesuatu adalah suatu kualitas tertentu yang menjadikan bendaitu lebih baik intrinsik daripada halnya, misalnya manusia ditinjau dari esensinya adalah berpikir.

c. Aksiden adalah keadaan khusus yang dapat berubah-ubah dan 
sifatnya kurang penting dibandingkan dengan esensialnya, misalnya orang suka barang-baran antik.

d. Subtansi adalah suatu kesatuan dari tiap-tiap hal individu dari yang khas dan yang universal, yang material dan yang spiritual.

Menurut Plato, perjalanan suatu benda dalam fisika menerangkan ada empat kausa:

1. Kausa materialis, yaitu bahan yang menjadi sususnan sesuatu benda, misalnya telur, tepung, dan gula untuk roti.

2. Kausa formalitas, yaitu dipandang dari formnya, bentuknya, atau modelnya, misalnya bulat, gepeng, dan lain-lain.

3. Kausa efisien, yaitu gerakan yang digunakan dalam pembuatan sesuatu cepat, lamabat, atau tergesagesa.

4. Kausa finalis adalah tujuan atau akhir dari sesuatu, dikatankanlah tujauan pembuatan sebuah patung.

\section{Epistemologi Perenialisme}

Perenialisme berpendapat
bahwa segala sesuatu yang dapat
diketahui dan merupakan kenyataan
adalah apa yang terlindung pada
kepercayaan. Kebenaran adalah sesuatu
yang menunjukkan kesesuaian antara
pikiran dan benda-benda. Benda-benda
di sini maksudnya adalah hal-hal yang

bersendikan prinsip-prinsip keabadian. Ini berati perhatian mengenai kebenaran adalah perhatian mengenai esensi dari sesuatu.

$$
\text { Kepercayaan terhadap }
$$

kebenaran itu akan terlindung apabila segala sesuatu dapat dikeetahui dan nyata. Jelaslah bahwa pengetahuan itu merupakan hal yang sangat penting kerena ia merupakan pengolahan akal pikiran yang konsekuen.

Menurut perenialisme, filsafat yang tertinggi adalah ilmu metafisika. Sebab sains sebagai ilmu pengetahuan menggunakan metode induktif yang bersifat analisis empiris kebenarannya terbatas, relatif, atau kebenaran probalitas. Akan tetapi, filsafat dengan metode deduktif bersifat analogical analysis, kebanaran yang dihasilkan bersifat self evidence unversal.

Ia berjalan dengan hukumhukum berpikir sendiri yang berpangkal pada hukum pertama, yaitu kesimpulannya bersifat mutlak asasi. Oleh karena itu,, menurut pereneliasme, perlu adanya dalil-dalil yang logis, nalar sehingga sulit diubah atau ditolak kebenarannya, seperti pada prinsipprinsip yang dikemukan oleh Aristoteles.

\section{Aksiologi Perenialisme}

Perenialisme memandang masalah nilai berdasarkan asas-asas supernatural, yaitu menerima universal 
yang abadi. Dengan asas seperti itu tidak hanya ontologi dan epistemologi yang didasarkan atas prinsip teologi dan supernatural, tetapi epistemologi. Khususnya, dalan tingkah laku manusia, manusia sebagai subjek telah memiliki potensi-potensi kebaikan sesuai dengan kodratnya. Di samping itu,, ada pula kecenderungan dan dorongan-dorongan ke arah yang tidak baik. Masalah nilai merupakan hal yang utama dalam perenialisme kerena berdasarkan pada asas-asas supernatural, yaitu universal yang abadi, khusunya tingkah laku manusia. Jadi hakikat manusia itu yang pertama-tama adalah jiwanya.

Oleh karena itu, hakikat manusia itu juga menentukan hakikat perbuatanperbutannya dan persoalan nilai adalah persoalan spiritual. Dalam aksiologi, prinsip pikiran itu bertahan dan tetap berlaku Secara etika.

Tindakan itu ialah yang bersesuaian dengan sifat rasional seseorang manusia kerena manusia itu secara almiah condong kepada kebaikan. Jadi, manuasia sebagai subjek dalam bertingkah laku telah memiliki potensi kebaikan sesuai dengan kodratnya, di samping ada pula kecenderungan-kecenderungan dan dorongan-dorongan ke arah yang tidak baik.

Tindakan yang baik adalah yang bersesuaian dengan sifat rasional (pikiran) manusia. Kodrat wujud manuasia yang pertama-tama tercemin dari jiwa dan pikirinnya yang disebut dengan kekuatan potensial yang membimbing tindakan manusia mujunu pada Tuhan atau menjauhi Tuhan. Dengan kata lain, melakukan kebaikan atau kejahatan, dan kebaikan tertinggi adalah mendekatkan diri pada Tuhan sessudah tingkatan ini baru kehidupan berpikir rasional. Pendidikan hendaknya berorientasi pada potensi itu kepada masyarakat agar kebutuahan yang ada pada setiap lapisan masyarakat bisa terpenuhi.

Dalam bidang pendidikan, perenialisme sangat dipengaruhi oleh tokoh-tokohnya seperti Plato, Aritoteles, dan Thomas Aquinas. Menurut Plato, manusia secara kodrat memiliki tiga potensi, yaitu nafsu, kemauan, dan pikiran. Pendidikan hendaknya berorentasi pada potensi itu kepada masyarakat agar kebutuhan yang ada pada setiap lapisan masyarakat bisa terpenuhi.

Dengan demikian, jelaskan bahwa perenialisme itu menghendaki agar pendidikan disesuaikan dengan keadaan manusia yang mempunyai nafsu, kemauan, dan pikiran sebagaimana yang dimiliki secara kodrat. Dengan memerhatikan hal ini, pendidikan yang berorientasi pada potensi dan masyarakat akan dapat 
terpenuhi. Ide-ide Plato ini kemudian dikembangkan oleh Aristoteles dengan lebih mendekatkan kepada dunia kenyataan. Bagi Aristoteles, tujuan pendidikan adalah kebahagian.

Untuk mencapai pendidikan itu, aspek jasmani, emosi, dan intelek harus dikembangkan secara seimbang. Zuhairini Arikonto di sini berpendapat dalam bukunya Filsafat Pendidikan Islam, betapa tujuan pendidikan yang dikehendaki oleh Thomas Aquinas tidak lain dimakudkan sebagai usaha mewujudkan kapasitas yang ada dalam individu agar menjadi aktualitas, aktif, dan nyata. Dalam hal in peranan guru pada anak didik adalah untuk mengembangkan potensi-potensi dipandang dan menetukan. Simpifikasi yang lain diberikan Robert Hutckins dengan mengatakan bahwa sebab manusia adalah animal rasionale, pendidikan harus diarahkan guna mengembangkan akal budi agar manusia dapat hidup penuh kebijaksanaan demi kebaikan hidup. Oleh karenanya, tujuan pendidikan di sekolah perlu sejalan dengan pandangan dasar di atas, mepertinggi kempuan anak untuk memiliki akal sehat.

Disini dapat disimpulalkan bahawa tujuan pendidikan yang hendak dicapai oleh perenialis bermaksud mewujudkan agar anak didik hidup bahagia demi kebaikan hidupnya.
Pengembangan akal diharapkan mampu mebekali anak didik dalam mempertinggi kemampuan akal pikirannya. Prisip ini sangat berpengaruh bagi sitem pendidikan modern, ketika kecerdasan nalar kerap menjadi hal yang begiyu mendapat perhatian lebih.

\section{Pendidikan Perenialisme}

Kaum perenialis berpandangan bahwa dalam dunia yang tidak menentu dan penuh kekacauan, serta membahayakan yang ditimbulkan akbat terjadinya krisis diberbagai dimensi kehidupan manusia (khususnya dalam pendidikan), tidak ada satupun yang lebih bermanfaat daripada kepastian tujuan pendidikan serta kestabilan dalam perilaku pendidik.

Dalam pemikiran itu, untuk menyelesaikan dan mengembalikan keadaan yang genting saat ini, perenialis memandang bahwa jalan keluar tidak ada yang lain kecuali kembali ke kebudayaan masa lampau yang dianggap sangat ideal dan teruji ketangguhannya.

Untuk itulah, pendidikan saat ini mesti lebih banyak mengarahkan pusat perhatiannya kepada kebudayaan masa lampau yang ideal serta telah teruji tangguh. Dapat disimpulkan perenialis memiliki pandangan yang bertolak terhadap modernistic yang telah menjauh dari tradisi dan terlalu 
mengedepankan logika dan rasio daripada sumber pengetahuan lainnya serta terlalu memandang sesuatu berdasarkan materi.

Jelaslah sekarang jika dikatakan bahwa pendidikan yang ada sekarang ini perlu kembali kepada masa lampau karena dengan mengembalikan keapaan (apa yang ada, apa yang terjadi, serta apa yang menjadi tujuan) pada masa lampau, kebudayaan yang dianggap krisis ini dapat teratasi melalui perenialisme karena ia dapat mengarahkan pusat perhatiannya pada pendidikan zaman dahulu dengan sekarang.

\section{A. Teori Pendidikan Perenialisme}

Perenialisme memandang pendidikan sebagai jalan kembali atau mengembalikan keadaan sekarang. Perenialisme memberikan sumbangan yang berpengaruh, baik berupa teori maupun praktik bagi kebudayaan dan pendidikan sekarang. Maka, dapat dikatakan bahwa perenialisme memandang pendidikan sebagai jalan kembali, yaitu sebagai suatu proses mengembalikan kebudayaan sekarang ini perlu dikembalikan ke kebudayaan masa lampau.

Perenialisme merupakan aliran filsafat yang mendasarkan pada kesatuan, bukan menceraiberaikan, bukan membanding- bandingkan. Maka dari itu dapat dikatakan bahwa perenialisme merupakan filsafat yang susunannya mempunyai kesatuan. Susunan tersebut merupakan hasil pikiran yang memberikan kemungkinan bagi seseorang untuk bersikap tegas dan lurus. Oleh karena itulah, perenialisme berpendapat bahwa mencari dan menemukan arah tujuan yang jelas merupakan tugas utama dari filsafat, khususnya filsafat pendidikan.

Setelah perenialisme terdesak karena perkembangan politik industry yang cukup berat , timbullah usaha untuk bangkit kembali dan perenialisme berharap agar manusia kini dapat memahami ide dan cita-cita filsafatnya yang menganggap sebagai suatu asa yang komperhensif. Perenialisme dalam makna filsafat dianggap sebagai satu pandangan hidup yang berdasarkan pada sumber kebudayaan dan hasilhasilnya.

Filsafat pernialisme memandang bahwa kepercayaan aksiomatis zaman kuno (tradisi dan kebudayaan masa lampau yang ideal) dan abad pertengahan perlu dijadikan penyusunan konsep filsafat pendidikan saat ini.

Sikap ini bukan merupakan romantisme ataupun nostalgia, 
melainkan terlah berdasarkan keyakinan bahwa kepercayaan tersebut berguna bagi abad sekarang. Jadi sikap untuk kembali ke masa lampau itu merupakan konsep bagi perenialisme, dengan kata lain, perenialisme menganggap pentingnya

Pembentukan kebiasaan dalam pendidikan sekarang yang berdasarkan pada kebiasaan dan kebudayaan pada masa lampau yang memiliki nilai integritas dan idealitas.

\section{B. Tujuan Pendidikan Perenialisme}

Bagi perenialis, nilai-nilai kebenaran bersifat universal dan abadi. Inilah yang menjadi tujuan pendidikan yang sejati. Oleh karena itu, tujuan pendidikan adalah membantu peserta didik menyiapkan dan menginternalisasikan nilai-nilai kebenaran yang abadi agar mencapai kebijakan dan kebaikan hidup.

Sekolah pada dasarnya sebuah tatanan buatan, yakni tempat para intelektual yang belum matang berkenalan dengan capaian terbesar manusia. Sekolah, seperti pandangan progresif, bukanlah miniature masyarakat yang lebih luas. Kehidupan manusia, dalam pengertian utuhnya, dapat dijalani hanya setelah aspek rasional manusia dikembangkan.

Sekolah adalah sebuah institusi khusus yang berupaya mencapai misi yang amat mulia. Sekolah tidak terlalu berkepentingan dengan persoalan semacam pekerjaan, hiburan dan rekreasi manusia. Ketiga hal ini memiliki tempat dalam kehidupan manusia, tetapi berada diluar lingkup aktifitas pendidikan.

Sekolah merupakan lembaga tempat latihan elite intelektual yang mengetahui kebenaran dan suatu waktu akan meneruskannya kepada generasi selanjutnya. Sekolah adalah lembaga yang berperan mempersiapkan peserta didik atau orang muda untuk terjun kedalam kehidupan. Sekolah bagi perenialis merupakan yang artificial tempat peserta didik berkenalan dengan hasil yang paling baik dari warisan sosial budaya.

Kurikulum pendidikan bersifat subject Connected, berpusat pada materi pelajaran. Materi pelajaran harus bersifat universal, seragam dan abadi. Selain itu, materi pelajaran terutama harus terarah kepada pembentukan rasionalitas manusia sebab demikianlah hakikat manusia. Mata pelajaran yang memiliki status tertinggi adalah 
mata pelajaran yang memiliki "Rational Content" yang lebih besar. Oleh karena itu, titik berat kurikulum diletakkan pada pelajaran sastra, matematika, bahasa dan humaniora, termasuk sejarah. Sedangkan sumber dan cara bmempelajari seni liberal tersebut dengan cara mempelajari the Greats book.

\section{Tokoh-Tokoh Perenialisme}

\section{Plato}

Plato (427-347 SM), hidup pada zaman kebudayaan yang sarat dengan ketidakpatian, yaitu filsafat sofisme. Ukuran kebenaran dan ukuran moral menurue sofisme adalah manusia secara pribadi, sehingga pada zaman itu tidak ada kepastian dalam moral, tidak ada kepastian dalam kebenaran, tergantung pada masing-masing individu. Bahaya perang dan kejahatan menggancam bangsa Athena. Siapa yang bisa memperoleh kebenaran secara retorik, dialah yang benar. Plato ingin membangun dan membina tata kehidupan yang ideal, di atas tata kebudayaan yang tertib dan sejahtera, membina cara yang menuju kebajikan.

Plato berpandangan bahwa realitas yang hakiki itu tetep tidak beubah. Realitas atau kenyataankenyataan itu telah ada pada diri manuasia sejak dari asalnya, yang berasal dari realitas yang hakiki. Menurut Plato, "dunia idea", bersumber dari ide mutlak, yaitu Tuhan. Kebenaran, pengetahuan, dan nilai sudah ada sebelum manusia lahir yang berumber dari ide yang mutlak tadi. Manusia tidak mengusahakan dalam arti memciptakan kebenaran, pengetahuan, dan nilai moral, melainkan bagaimana menusia menemukan semuanya itu. Dengan menggunakan akal atau rasio, semuanya itu dapat ditemukan kembali oleh manuisa.

Kebenaran itu ada, yaitu kebenaran yang bulat dan utuh. Manusia dapat memperoleh kebenaran tersebut dengan jalan berpikir, bukan dengan pengamatan indera, karena dengan berpikir itulah manusia dapat mengetaui hakikat kebenaran dan pengetahuan. Dengan indera, manusia hanya sampai pada memperkiraan. Manusia hendaknya memikirkan, menyelidiki dan mempelajari dirinya sendiri dan keseluruhan alam semesta.

Esensi realitas, pengetahuan, dan nilai merupakan manifestasi dari hukum universal yang abadi dan sempurna, yaitu ide mutlaj yang merupakan supernatural. Ketertiban 
sosial hanya akan mungkin apabila ide tersebut dijadikan standar, atau dijadikan atas normatif dalam segala aspek kehidupan. Tujuan utama pendidikan adalah mebina pemimpin yang sadar akan asas normatif tersebut dan melaksanakannya dalam semua aspek kehidupan.

Masyarakat yang ideal adalah masyarakat adil sejehtera. Masyarakat ini lahir apabila setiap warga negara melaksanakan fungsi sosialnya sesuai dengan tingkat kependudukan dan kemampuan pribadinya. Manusia yang terbaik adalah manusia yang hidup atas dasar prinsip "idea mutlak". Ide mutlak inilah yang membimbing manusia untuk menemukan kriteria moral, politik, dan sosial, serta keadilan. Ide mutlak adalah suatu prinsip mutlak yang menjadi sumber realitas semesta dan hakikat kebenaran abadi yang transendental. Ide mutlak adalah pencipta alam semseta, yaitu Tuhan.

\section{Aristoteles}

Aristoteles (384-322 SM), adalah murid Plato, namun dalam pemikirannya ia mereaksi terhadap filsafat gurunya, yaitu idealisme. Hasilnya pemikirannya disebut filsafat realisme (realisme klasik). Cara berpikir Aristoteles berbeda dengan gurunya, Plato yang menekankan berpikir rasional spekulatif. Aristoteles mengambil cara berpikir rasional empiris realitis. Ia mengajarkan cara berpikir atas prinsip ralistis, yang dekat pada alam kehidupan manusia sehari-hari.

Aristoteles hidup pada abad keempat Sebelum Masehi, namun dia dinyatakan sebagai pemikir adab petengahan. Karya-karya Aristoletes merupakan dasar berpikir abad pertengahan yang melahirkan renaissance. Sikap positifnya terhadap inkuiri menyebabkan ia mendapat sebutan sebagai Bapak Sains Modern. Kebajiakn akan menghasilkan kebahagian dan kebaikan, bukanlah pernyataan pemikiran atau perenungan pasif, melainkan merupakan sikap kemauan yang baik dari manusia.

Menurut Aristoteles, manusia adalah makhluk materi dan rohani sekaligus. Sebagai materi, ia manyadari bahwa manusia dalam hidupnya berada dalam kondisi dalam materi dan sosial. Sebagai makhluk rohani manusia sadar ia akan menuju pada proses yang lebih tinggi yang menuju kepada manusia ideal, manusia sempurna. Manusia sebagai hewan rasional memiliki 
kesadaean intelektual dan spiritual, ia hidup dalam alam materi sehingga akan menuju pada derajat yang lebih tinggi, yaitu kehidupan yang abadi, alam supernatural.

\section{Thomas Aquinas}

Thomas Aquina mencoba mempertemuak suatu pertentangan yang muncul pada waktu itu, yaitu antara ajaran Kristen dengan filsafat (sebetuknya dengan filsafat Aritoteles, sebab pada waktu itu yang dijadikan dasar pemikiran logis adalah filsafat noeplatonisme dari Plotinus yang dikembangkan oleh St. Agustinus). Menurut Aquina tidak terdapat pertentangan antara filsafat (khususnya filsafat Aristoteles) dengan ajaran agama (Kristen). Keduanya dapat berjalan dalam lapangannya masing-masing. Thomas Aquina secara terus terang dan tanpa ragu-ragu mendasarkan filsafatnya kepada filsafat Aristoteles.

Pandangan tentang realistis, ia mengemukakan, bahwa segala sesuatu yang ada, adanya itu karena diciptakan olej Tuhan, dan tergantung kepada-Nya. Ia mempertahankan bahwa Tuhan, bebas dalam menciptakan dunia. Dunia tidak mengalir dari Tuhan bagaikan air yang mengalir dari sumbernya, seperti hanlnya yang dipikirkan oleh filosof neoplatonisme dalam ajaran mereka tentang teori "emansi" Thomas Aquina menekankan dua hal dalam pemikiran tentang realitas, yaitu : 1 ) dunia tidak diadakan dari semacam bahan dasar, dan 2) penciptaan tidak terbatas pada satu saat saja, demikian menurut Bertens (1979).

Dalam masalah pengetahhuan, Thomas Aquina mengemukakan bahwa pengetahuan itu diperoleh sebagai persentuhan dunia luar dan oleh akan budi, maenjadi pengetahuan. Selain pengetahuan manusia yang bersumber dari wahyu, manusia dapat meperoleh pengetahuan melalui pengelaman dan rasionya (di sinilah ia mempertemukan pandagan filsafat idealisme, realisme, dan ajaran gereja). Filsafat Thomas Aquina disebut tomisme. Kadang-kadang orang tidak membedakan antara perenialisme dengan noetomisme. Perenialisme adalah sama dengan noetomisme dalam pendidikan.

\section{Perenialisme Dalam Pembelajaran Sejarah \\ Metode pembelajaran yang} digunakan oleh para kaum perenialis adalah membaca dan diskusi, yaitu membaca dan mendiskusikan karya- 
karya yang termashur dalam rangka mendisplinkan pikiran.

Guru berperan bukan sebagai perantara antara dunia dan jiwa anak, melainkan guru juga sebagai murid yang mengalami proses belajar. Disamping mengembangkan potensi self-discovery, ia juga melakukan otoritas moral kepada murid-muridnya karena guru memposisikan seorang yang professional yang qualified dan superior dibandingkan dengan muridnya. Guru harus memiliki aktualitas yang lebih dan pengetahuan yang sempurna.

\section{Daftar Pustaka}

Agastya. Vol 01 N0. 02 Juli 2011. Jurnal Sejarah dan Pembelajarannya. Madiun:

Prodi Pendidikan Sejarah IKIP PGRI Madiun.

Barnadib, Iman. 1976. Filsafat Pendidikan Sistem Dan Metode. Yogyakarta : Andi Offset.

HW, Teguh Wangsa Gandhi. Filsafat Pendidikan. Jogyakarta : Ar-Ruzz Media.

Sadulloh, Uyoh. 2004. Pengantar Filsafat Pendidikan. Bandung : Alfabeta. Suharto, Suparlan. 2007. Filsafat

Pendidikan. Jogyakarta : Ar-Ruzz Media

Group 